\title{
ABUNDANCE, DAMAGE SEVERITY AND MANAGEMENT OF GUAVA MEALYBUG, FERRISIA VIRGATA Ckll
}

\author{
M.M.H. Khan* \\ Department of Entomology, Patuakhali Science and Technology University \\ Dumki, Patuakhali, Bangladesh.
}

\begin{abstract}
The research was carried out to know the abundance and damage severity of mealybug on sarupkathi variety of guava and to evaluate the efficacy of jet powder and Fighter 2.5EC for suppressing populations of mealybug during January to October 2014. Results revealed that the highest number of guava mealybug was observed on middle leaf (42/leaf) while the lowest number was on lower leaf (13/leaf). The highest percent leaf area covered by mealybug was found on middle leaf $(78 \%)$ while the lowest was on fruit (18\%). Maximum temperature and relative humidity had a positive correlation on the mealybug population while the rainfall showed a negative correlation. The highest percent mortality was observed in $\mathrm{T}_{2}$ treatment (Jet powder applied @ $5.0 \mathrm{~g} \mathrm{~L}^{-1}$ of water) at 24 HAT (hours after treatment) (86.05\%) and 48 HAT (93.83\%), respectively. At 72 HAT, the highest percent mortality was observed $\mathrm{T}_{3}$ treatment (Jet powder applied @ $7.5 \mathrm{~g} \mathrm{~L}^{-1}$ of water). In case of insecticidal control, the highest percent mortality was observed in $\mathrm{T}_{2}$ $(100 \%)$ and $T_{3}(100 \%)$ treatments, respectively followed by $T_{1}(98.03 \%)$ at 24 HAT. Similar trends were also observed among all treatments at 48 HAT and 72 HAT, respectively. No significant differences were found among three doses of Fighter 2.5EC. The lowest percent mortality of mealybug population was found in $\mathrm{T}_{4}$ (Water spray forcibly) at 24 HAT, 48 HAT and 72 HAT, respectively. No mortality was recorded in untreated control at different HAT in both application of soap solution and insecticides.
\end{abstract}

Keywords: Ferrisia virgata, Psidium guajava, jet, fighter 2.5EC, meteorological factors

\section{INTRODUCTION}

Guava (Psidium guajava: Myrtaceae) known as the apple of the tropics and is one of the most common and popular delicious fruits in Bangladesh. It is very rich in

\footnotetext{
*Corresponding author email: mohasin1965@pstu.ac.bd
} 
vitamin C. Some varieties of guava such as Kazipiara, Kanchannagar, Mukundapuri and Swarupkathi grow everywhere in the country in the homestead gardens but commercially cultivated in Barisal, Sylhet and Chattogram regions. There are several species of mealy bugs that can be pests of greenhouse, nursery, and landscape plants. Nearly 246 families of various plants on which 5000 species of mealybug feed that have been reported all over the world (Ben-Dov, 1994). According to Afzal et al. (2009) and Aheer et al. (2009), mealybugs feed on nearly 149 plant species, suck plant sap and cause leaves to distort and fall. Mealy bugs are causing loss to different fruit plants namely citrus, guava, grapes, pomegranate, chiku, jamun and aonla. Guava mealybug (Ferrisia virgata Ckll.) is one of the most commonly occurring pests found on the fruit crops causing damage to guava and several host plants (Wabale et al., 2010). Mealybugs damage plants by inserting their threadlike mouthparts into any part of the plant and sucking out sap (Frank, 2011). Both nymphs and adult females of these mealybugs suck cell sap from different parts of the plant like the leaves, twigs, tender shoots, branches and fruits thereby reducing the vigour of plant as well as the drying up the tender shoots. They excrete honeydew, a sweet sticky liquid on which sooty moulds often grow causing infested plants to turn black. Considering above facts, the present research work was undertaken to know the abundance and damage severity of mealybug on guava and to evaluate the efficacy of detergents and insecticides for suppressing population of mealybug.

\section{MATERIALS AND METHODS}

The study was carried out in the Department of Entomology, Patuakhali Science and Technology University (PSTU) during January to October 2014. Geographically, the research farm is located at $22^{0} 37^{\prime} \mathrm{N}$ latitude and $89^{\circ} 10^{\prime} \mathrm{E}$ longitudes. The area is covered Gangetic Tidal Floodplains and falls under Agroecological Zone "AEZ- 13". The area lies at 0.9 to 2.1 metre above mean sea level (Iftekhar and Islam, 2004). The experimental area experiences sub-tropical climate with high temperature and it decreased when the season proceeded towards rabi (October to March).

\section{Abundance and damage severity of guava mealybug}

A total of 10 plants were selected as host of mealybug. The age and height of the plants were 5 years and 9 feet, respectively. Infested plants were examined using a magnifying glass. Infested leaves, twigs and fruits were collected from the plants and placed separately in poly bags for further examination in the laboratory. The collected specimens were counted, processed, mounted and labeled for preservation. Number of mealybugs per 5 leaves on different leaf categories viz upper, middle and lower, twig and fruits of each guava plant were recorded. The data were collected on weekly intervals. The percent leaf area covered by mealybugs was recorded by eye estimation. 


\section{Collection of meteorological data}

Meteorological data on maximum and minimum temperature, relative humidity and rainfall were collected from the Patuakhali district meteorological office.

\section{Evaluation of the efficacy of detergent and insecticide for controlling mealybug}

The trial was conducted in completely randomized design with three replications. The infested leaves of different plant canopies were collected from highly infested guava plants and brought back to the laboratory. Thirty mealybugs of nymphs and adults were released on each leaf which was kept in Petri dish. Three doses of Jet powder were used as three treatments where $\mathrm{T}_{1}=2.5 \mathrm{~g} \mathrm{~L}^{-1}$ of water, $\mathrm{T}_{2}=5.0 \mathrm{~g} \mathrm{~L}^{-1}$ of water and $\mathrm{T}_{3}=7.5 \mathrm{~g} \mathrm{~L}^{-1}$ of water along with a control. On the other hand, three doses of Fighter 2.5 EC were used as three treatments where $\mathrm{T}_{1}=1.0 \mathrm{ml} \mathrm{L}^{-1}$ of water, $\mathrm{T}_{2}=$ $1.5 \mathrm{ml} \mathrm{L}^{-1}$ of water and $\mathrm{T}_{3}=2 \mathrm{ml} \mathrm{L}^{-1}$ of water along with a control. The spraying was done with hand sprayer. After spraying the treated leaves were put on soaked filter paper by keeping these in Petri dish separately. The Petri dishes were arranged in three rows following CRD. One row of Petri dishes constituted one replication and a total of 15 Petri dishes were used in this experiment. However, control leaves received no treatment. Observations were recorded on the mortality of mealybugs at 24, 48 and 72 hours interval and cumulative data were calculated for interpretation.

\section{Statistical analysis}

Data were analyzed following single factor ANOVA using MSTAT-C computer software. Means were separated by LSD test. The correlations were worked out between mealy bug population and weather parameters of study period.

\section{RESULTS AND DISCUSSION}

The number of mealybug population on various parts of guava plant is presented in Fig. 1. The highest number of mealybug per plant was recorded on middle leaf (42) followed by upper leaf (26) while the lowest number was on fruit (6) followed by twig (9) and lower leaf (13).

Figure 2 revealed the damage severity of mealybug through area covered by mealybug on different parts of guava plant. The highest percent leaf area covered by mealybug was found on middle leaf $(78 \%)$ followed by upper leaf $(63 \%)$ while the lowest was in fruit (18\%) followed by twig (25\%) and lower leaf (33\%). 


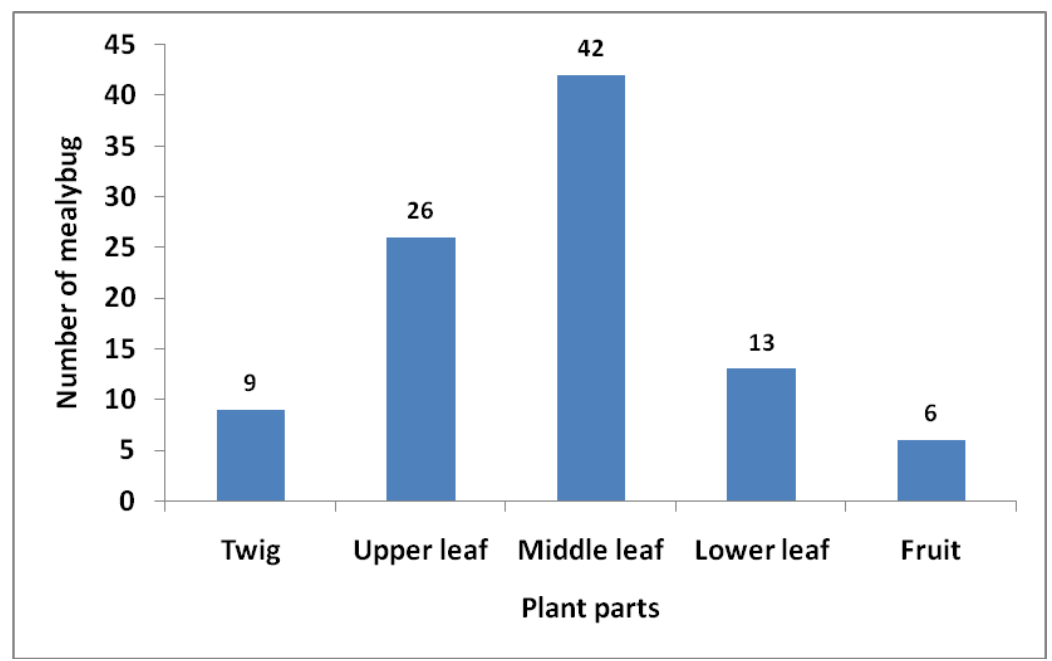

Figure 1. Abundance of mealybug on different plant parts of guava

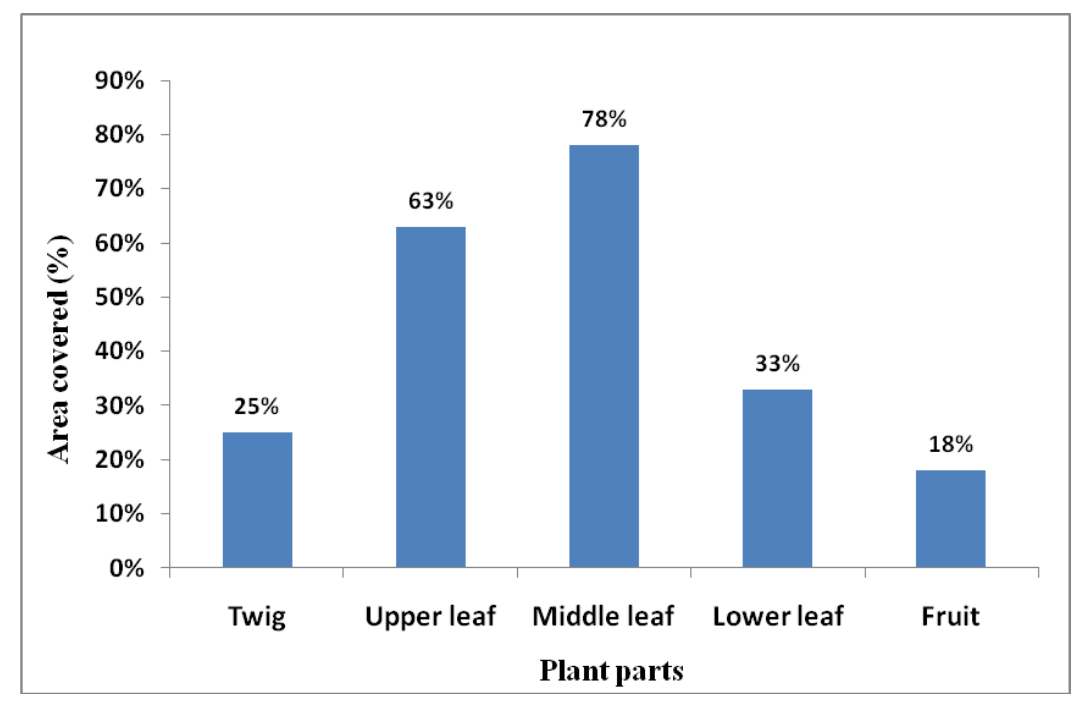

Figure 2. Area covered by mealybug on different parts of guava

The variation in the number of mealybug on different plant parts might be due to the variation of various chemical compounds in guava. It has been reported that leaves on the same plant or even in the same twig may display up to four-fold differences in concentrations of various compounds (Schultz, 1983). The results of the present study are in agreement with the findings of Sultana et al. (2015) who reported the similar trend of mealybug population on different leaf categories of guava. This finding was also supported by Wabale et al. (2010). 


\section{Relationship of mealybug population with weather factors}

Temperature, humidity and rainfall have had tremendous effect on mealybug population. There was a positive correlation $(r=0.620)$ between population of guava mealybug and average maximum temperature. It indicates that the populations of mealybug gradually increased with increasing temperature. The contribution of the regression $\left(\mathrm{R}^{2}=0.385\right)$ was $39 \%$ (Fig. 3 ). The population of mealybug was also positively correlated with average relative humidity $(\mathrm{r}=0.613)$. It indicates that the populations of mealybug gradually increased with increasing average relative humidity. The contribution of the regression $\left(\mathrm{R}^{2}=0.376\right)$ was $38 \%$ (Fig. 4). On the other hand, there was a negative correlation $(r=0.767)$ between population of guava mealybug and average rainfall. It indicates that the populations of mealybug gradually decreased with increasing average rainfall. The contribution of the regression $\left(\mathrm{R}^{2}=0.588\right.$ ) was $59 \%$ (Fig. 5). The findings are supported by Mani and Thontadarya (1978) who stated that maximum temperature had a positive correlation the mealybug population while the relative humidity showed a negative correlation. The influence of relative humidity was contradict with the findings of the present study. Manjunath (1985) reported that the bug was present throughout the year, there being peak period of infestation during February to March. Babu and Azam (1987) reported that the mealybug population was abundant by March on grapevine. Rainfall appeared to have a tremendous negative effect on mealybug population. The population of guava mealybug gradually decreased after May with increasing rainfall and was the lowest in the month of July due to high rainfall (Fig. 5). Koli (2003) reported that mealybug showed non-significant negative correlation with rainfall on grapes.

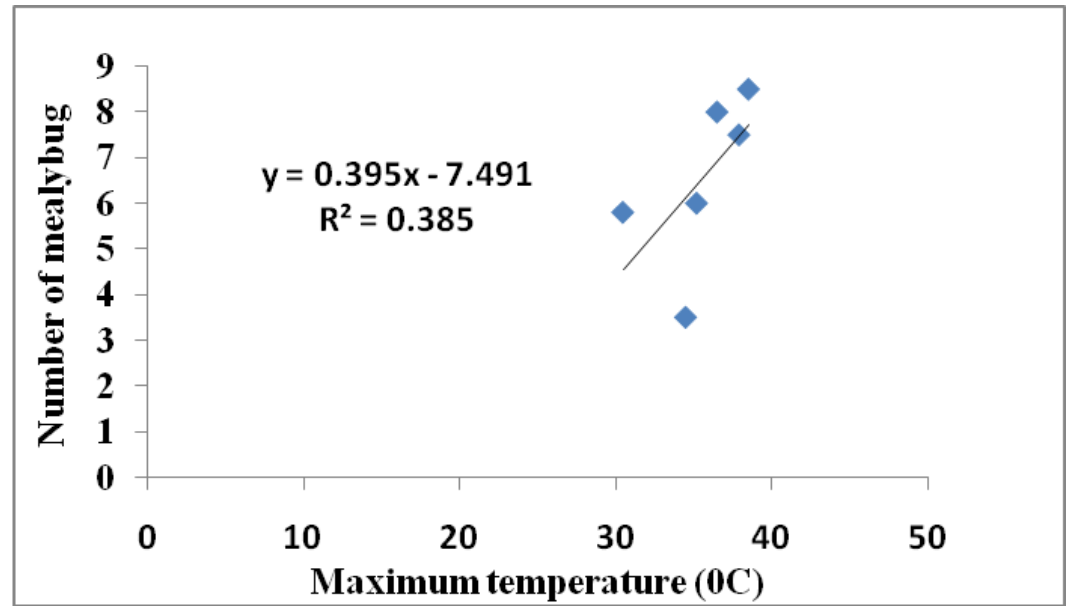

Figure 3. Relationship between mealybug population with maximum temperature in guava 


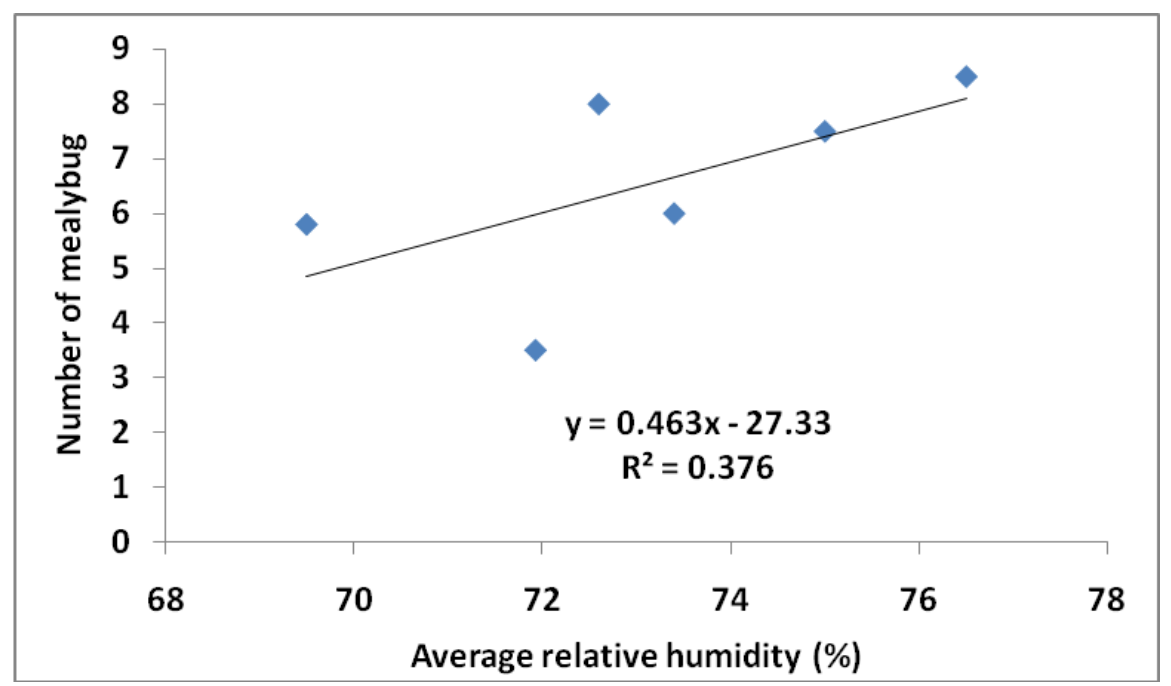

Figure 4. Relationship between mealybug population with average relative humidityin guava

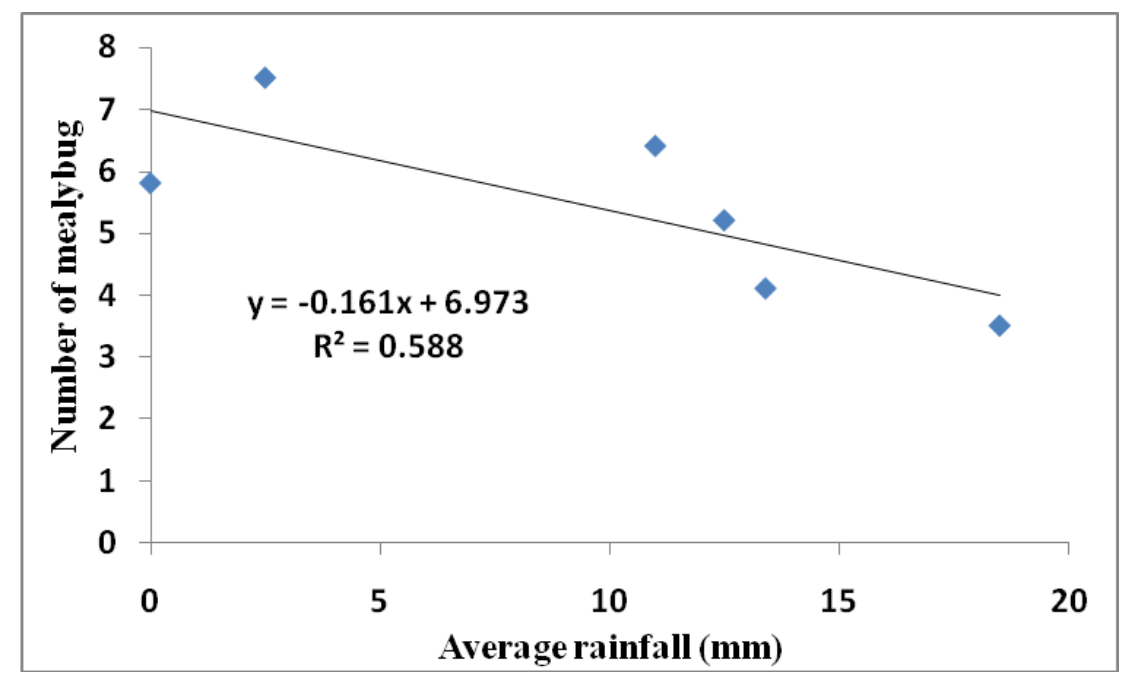

Figure 5.Relationship between mealybug population with average rainfall on guava

\section{Management of mealybug}

Effect of different doses of wheel powder and water on mortality of mealybug

The mortality of mealybug population ranged from $0.00 \%$ to $86.05 \%$ after 24 hours of treatment application (Table 1). Significantly the highest $(86.05 \%)$ mortality was 
observed $\mathrm{T}_{2}$ treatment (Jet powder applied @ $5.0 \mathrm{~g} \mathrm{~L}^{-1}$ of water) followed by $\mathrm{T}_{3}$ (81.21\%) (Jet powder applied @ $7.5 \mathrm{~g} \mathrm{~L}^{-1}$ of water) and $\mathrm{T}_{1}(74.49 \%)$ (Jet powder applied @2.5 $\mathrm{g} \mathrm{L}^{-1}$ of water). The lowest percent $(19.81 \%)$ mortality of whitefly population was found in $\mathrm{T}_{4}$ (Water spray forcibly). No mortality was recorded in untreated control. After 48 hours of treatment application, the highest $(93.83 \%)$ mortality was observed $\mathrm{T}_{2}$ treatment (Jet powder applied @ $5.0 \mathrm{~g} \mathrm{~L}^{-1}$ of water) which was statistically similar to $\mathrm{T}_{3}(92.82 \%)$ (Jet powder applied @ $7.5 \mathrm{~g} \mathrm{~L}^{-1}$ of water) followed by $\mathrm{T}_{1}(87.19 \%)$ (Jet powder applied @2.5 $\mathrm{g} \mathrm{L}^{-1}$ of water). The lowest percent $(4.18 \%)$ mortality of mealybug population was found in $\mathrm{T}_{4}$ (Water spray forcibly). No mortality was also recorded in untreated control. After 72 hours of treatment application, the highest $(97.65 \%)$ mortality was observed $\mathrm{T}_{3}$ treatment (Jet powder applied @ $7.5 \mathrm{~g} \mathrm{~L}^{-1}$ of water)which was statistically similar to $\mathrm{T}_{2}(95.90 \%)$ (Jet powder applied @ $5.0 \mathrm{~g} \mathrm{~L}^{-1}$ of water) followed by $\mathrm{T}_{1}(93.48 \%)$ (Jet powder applied @2.5 g L $\mathrm{g}^{-1}$ of water). The lowest percent (3.18\%) mortality of mealybug population was found in $\mathrm{T}_{4}$ (Water spray forcibly). No mortality was also recorded in untreated control. Application techniques and force of liquid on the target surface may influence the effectiveness of detergents. The efficacy of Jet powder in the mortality of mealybug population is for the eliminating properties of the waxy layer of the pest along with viscosity. Use of detergents against sucking like mealybugs and whitefly has been reported by other authors. Spraying a steady stream of water with reasonably high pressure on the host plant to knock-off mealybugs. Once on the ground, the fallen ones will be available to ground predators and this will also make their return to the plant difficult. Spraying with a soap and water solution is reported to control mealybugs. Good spray coverage and good timing is important when using soapy solutions and oils. To be effective they must come in contact with the mealybugs. Crawlers are the easiest to kill, since they are more susceptible and are more exposed than eggs, older nymphs and adults. Use of mild solution of soap, mixing an inexpensive liquid dish washing detergent @ 1 tablespoon per gallon of water, and thoroughly spraying the underside of infested leaves can control the guava whitefly (CABI, 1999). Puri et al. (1994) reported that the detergent Nirma, Rin, Surf and Wheel powder at concentration of $0.25,0.5$ and $1 \%$ reduced the sweet potato whitefly Bemisia tabaci (Gennadious) adults by $69-91 \%$ and nymph by $97-99 \%$.

Table 1. Effect of jet powder on the mortality of mealybug infesting guava at different time interval in laboratory condition

\begin{tabular}{l|c|c|c|c}
\hline \multirow{2}{*}{ Treatment } & Dose & \multicolumn{3}{|c}{$\begin{array}{c}\text { Mortality (\%) at different hours after treatment (HAT) } \\
\text { application }\end{array}$} \\
\cline { 3 - 5 } & & $24 \mathrm{HAT}$ & $48 \mathrm{HAT}$ & $72 \mathrm{HAT}$ \\
\hline $\mathrm{T}_{1}$ & $2.5 \mathrm{gL}^{-1}$ of water & $74.49 \mathrm{c}$ & $87.19 \mathrm{c}$ & $93.48 \mathrm{~b}$ \\
$\mathrm{~T}_{2}$ & $5.0 \mathrm{gL}^{-1}$ of water & $86.05 \mathrm{a}$ & $93.83 \mathrm{a}$ & $95.90 \mathrm{ab}$ \\
$\mathrm{T}_{3}$ & $7.5 \mathrm{gL}^{-1}$ of water & $81.21 \mathrm{~b}$ & $92.82 \mathrm{ab}$ & $97.65 \mathrm{a}$ \\
\hline
\end{tabular}




\begin{tabular}{l|c|c|c|c}
\hline \multirow{2}{*}{ Treatment } & Dose & \multicolumn{3}{|c}{$\begin{array}{c}\text { Mortality (\%) at different hours after treatment (HAT) } \\
\text { application }\end{array}$} \\
\cline { 3 - 5 } & & $24 \mathrm{HAT}$ & $48 \mathrm{HAT}$ & $72 \mathrm{HAT}$ \\
\hline $\mathrm{T}_{4}$ & Water spray & $19.81 \mathrm{~d}$ & $4.18 \mathrm{~d}$ & $4.18 \mathrm{c}$ \\
$\mathrm{T}_{5}$ & Untreated & $0.00 \mathrm{e}$ & $0.00 \mathrm{e}$ & $0.00 \mathrm{~d}$ \\
\hline LSD $(5 \%)$ & 1.74 & 1.02 & 1.81 \\
\hline $\mathrm{CV}(\%)$ & 3.41 & 3.07 & 3.23 \\
\hline
\end{tabular}

Means in a column followed by same letter(s) did not differ significantly at $5 \%$ level by LSD Values are averages of three replications.

\section{Efficacy of various doses of Fighter 2.5 EC on the mortality of mealybug}

At 24 HAT, the highest percent mortality was observed in $\mathrm{T}_{2}(100 \%)$ and $\mathrm{T}_{3}(100 \%)$ treatments, respectively followed by $\mathrm{T}_{1}(98.03 \%)$. No significant differences were found among three doses of Fighter 2.5EC. The lowest percent mortality (18.00\%) was recorded in $\mathrm{T}_{4}$ treatment when only water was applied forcibly on infested leaves. No mortality was observed in untreated control. Similar trends were also observed among all treatments at 48 HAT and 72 HAT, respectively (Table 2).

Table 2. Efficacy of various doses of Fighter 2.5 EC on the mortality of mealy bug infesting guava at different time interval in laboratory condition

\begin{tabular}{l|c|c|c|c}
\hline \multirow{2}{*}{ Treatment } & \multicolumn{1}{|c|}{ Dose } & \multicolumn{3}{|c}{ Mortality (\%) at different hours after treatment } \\
& & & $48 \mathrm{HAT}$ & $72 \mathrm{HAT}$ \\
\cline { 3 - 5 } & & $24 \mathrm{HAT}$ & $100.00 \mathrm{a}$ & $100.00 \mathrm{a}$ \\
$\mathrm{T}_{1}$ & $1.0 \mathrm{ml} \mathrm{L}^{-1}$ of water & $98.03 \mathrm{a}$ & $100.00 \mathrm{a}$ & $100.00 \mathrm{a}$ \\
$\mathrm{T}_{2}$ & $1.5 \mathrm{ml} \mathrm{L}^{-1}$ of water & $100.00 \mathrm{a}$ & $100.00 \mathrm{a}$ & $100.00 \mathrm{a}$ \\
$\mathrm{T}_{3}$ & $2.0 \mathrm{ml} \mathrm{L}^{-1}$ of water & $100.00 \mathrm{a}$ & $22.00 \mathrm{~b}$ & $22.00 \mathrm{~b}$ \\
$\mathrm{~T}_{4}$ & Water spray & $18.00 \mathrm{~b}$ & $0.00 \mathrm{c}$ & $0.00 \mathrm{c}$ \\
$\mathrm{T}_{5}$ & Untreated & $0.00 \mathrm{c}$ & 0.03 & 0.02 \\
\hline LSD $(5 \%)$ & & 0.06 & 1.07 & 1.05 \\
\hline $\mathrm{CV}(\%)$ & & 1.06 & \\
\hline
\end{tabular}

Means in a column followed by same letter(s) did not differ significantly at $5 \%$ level by LSD

Values are averages of three replications.

From the results of Table 1 and 2 it was observed that Jet powder applied at the rate $5.0 \mathrm{~g} \mathrm{~L}^{-1}$ of water at 24, 48 and 72 hours after application provided the effective control of mealybug population in laboratory condition. Likewise, three doses of Fighter $2.5 \mathrm{EC}$ were found to be effective in controlling mealybug in laboratory condition.

The results of the present study are in agreement with the findings of Sultana et al. (2015). The effective control of guava mealybug by using insecticides is also 
reported by Baskaran et al. (1999). They found that, $F$. virgata was the dominant coccid species, infesting 98 per cent of guava trees, followed by $M$. hirsutus. Monocrotophos $(0.072 \%)$, malathion $(0.25 \%)$, dimethoate $(0.06 \%)$ and phosalone $(0.175 \%)$ were evaluated for $F$. virgata control. Dimethoate and malathion were most effective in controlling $F$. virgata. Guava leaf disks were offered to $F$. virgata after treating with phosalone $(0.175 \%)$, phosphamidon $(0.086 \%)$, monocrotophos $(0.072 \%)$, dichlorvos $(0.1 \%)$, malathion $(0.25 \%)$ and dimethoate $(0.06 \%)$ by leaf dipping and leaf spraying. The leaf dip assay was most effective, recording cent per cent mortality at $24 \mathrm{~h}$ after treatment. Beevi et al. (1992) tested ten insecticides as sprays in laboratory against eggs of mealy bug, $M$. hirsutus. Hatching was least in eggs treated with neem oil $(0.3 \%)$ followed by moncrotophos $(0.04 \%)$, methyl demeton $(0.04 \%)$ and fish oil rosin soap $(2.5 \%)+$ dichlorvos $(0.2 \%)$.

\section{CONCLUSIONS}

The highest number of guava mealybug was observed on middle leaf of guava. Populations of mealybug increased with increasing temperature and relative humidity and decreased with increasing rainfall. Application of jet powder @ $5.0 \mathrm{~g} \mathrm{~L}^{-1}$ of water and three doses $\left(1.0 \mathrm{ml}, 1.5 \mathrm{ml}\right.$ and $2.0 \mathrm{ml} \mathrm{L}^{-1}$ of water) of Fighter $2.5 \mathrm{EC}$ at 24,48 and 72 HAT were found effective in controlling mealybug population in laboratory condition.

\section{ACKNOWLEDGEMENTS}

Author is grateful to the authority of PSTU for financial assistance to accomplish this project and also to Head, Department of Entomology for providing laboratory facilities during the study period.

\section{REFERENCES}

Afzal, M., Rahman, S.U., and Siddiqui, M.T. (2009). Appearance and management of a new devastating pest of cotton, Phenacoccus solenopsis Tinsley, in Pakistan. Belt-wide Cotton Conference, San Antonio, Texas, pp. 5-8.

Aheer, G.M., Shah, Z., and Saeed, M. 2(009). Seasonal history and biology of cotton mealy bug, Phenacoccus solenopsis Tinsley. Journal of Agricultural Research, 47 (4): 423 431.

Ahmed, N.H., and Abd-Rabou, S. (2010). Host plants, geographical distribution, natural enemies and biological studies of the citrus mealy bug, Planococcus citri (Risso) (Hemiptera: Pseudococcidae). Egyptian Academic Journal of Biological Sciences, 3 (1): 39-47.

Babu, T.R., and Azam, K.M. (1987). Studies on biology, host spectrum and seasonal population fluctuation of the mealy bug, Maconellicoccus hirsutus (Green) on grapevine. Indian Journal of Horticulture, 44(3-4): 284-288.

Baskaran, R.K.M., Lakshmi, L.G., and Uthamasamy, S. (1999). Coccids and their management in guava intercropped with coconut. Pest Management in Horticultural Ecosystems, 5(1): 28-31. 
Ben-Dov, Y. (1994). A systematic catalogue of the mealybugs of the world, Intercept Limited, UK, 686p.

Beevi, N.D., Janarthanan, R., and Natarajan, K. (1992). Efficacy of some insecticides against Maconellicoccus hirsutus (Green) on mulberry. Journal of Insect Science, 5(1): 114.

CABI. (1999). Crop Protection Compendium, Global Module. edition. CABI, Wallingford, U.K.

Cham, D., Davis, H., Obeng-Ofori, D., and Owusu, E. (2011). Host range of the newly invasion mealybug species Paracoccus marginatus Williams and Granara De Willink (Hemiptera: Pseudococcidae) in two ecological zones of Ghana. Research in Zoology, 1 (1): $1-7$.

Evans, H.E. (1984). Insect Biology: A textbook of Entomology. Addison-Wesley Publishing Company, Massachusetts-California-London-Amsterdam-Ontario-Sydney. 436p.

Frank, S.D. (2010). Ornamental and Turf mealybugs. http://www.ces.ncsu.edu/depts/ ent/notes/O\&T/flowers/note19/note19 Date: 15/5/2013

Frank, S. D. (2011). Mealy bugs. http://mrec.ifas.ufl.edu/Iso/Mealybugs.htm Date: 15/5/2013

Heu, R.A., Fukada, M.T., and Conant, P. (2007). Papaya mealybug, Paracoccus marginatus Williams and Granara de Willink (Hemiptera: Pseudococcidae). State of Hawaii New Pest Advisory. De-partment of Agriculture No. 04-03 March 2007.

Iftekhar, M.S., and Islam, M.R. (2004). Managing mangroves in Bangladesh: A strategy analysis, Journal of Coastal Conservation, 10: 139-146.

Koli, H.R. (2003). Seasonal incidence and management of grape mealy bug, Maconellicoccus hirsutus (Green). M.Sc. (Agri.) Thesis, Mahatma Phule Krishi Vidhyapeeth, Rahuri, Maharashtra (India).

Mani, M., and Thontadarya, T.S. (1987). Population dynamics of the mealy bug, Maconellicoccus hirsutus (Green) and its natural enemies in the grapevine ecosystem. Journal of Biological Control, 1(2): 93-97.

Manjunath, T.M. (1985). India- Maconellicoccus hirsutus on grapevine. FAO Plant Protection Bulletin, 33(2): 74.

Puri, S.N., Bhosle, B.B., Ilyas, M., Butler, G.D., and Homeberry, T.J. (1994). Detergents and plant derivatives oils for control of the sweet potato whitefly on cotton. Crop Protection, 13(1): 45-48.

Schultz, J.C. (1983). Habitat selection and foraging tactics of caterpillars in heterogeneous trees. pp. 61-90. In: Denno, R.F. and M.S. Mcclure (ed.). Variable Plants and Herbivores in Natural and Managed Systems. Academic Press, New York. pp. 61-90.

Sultana, I., Khan, M.M.H., and Rahman, M.H. (2015). Incidence of guava mealy bug, Ferrisia virgata Ckll and its management. Bangladesh Journal of Entomology, 25(2): 13-22.

VanZile, J. 2013. Mealy bugs- How to Control Mealy bugs.

Wabale, A.S., Jadhav, V.G., Vane, A.D., and Nale, B.V. (2010). Efficacy of Balanites aegyptiaca (L.) Delli Leaf Extract against Mealy bug (Ferrisia virgata Ckll.). Asian Journal of Experimental Biological Sciences, SPL. : 112-114.

Williams, D.J. (1996). A brief account of the hibiscus mealybug Maconellicoccus hirsutus (Hemiptera: Pseudococcidae), a pest of agriculture and horticulture, with descriptions of two related species from southern Asia. Bulletin Entomological Research, 86: 617628. 